\title{
Inflation persistence in African countries: Does inflation targeting matter?
}

\author{
Andrew Phiri* \\ School of Economics, Faculty of Economic and Management Sciences, North West University, South Africa
}

Received: 2 June 2016

Revised: 17 August 2016

Accepted: 19 August 2016

\begin{abstract}
This study investigates inflation persistence in annual CPI inflation collected between 1994 and 2014 for 46 African countries. We group these countries into panels according to whether they are inflation targeters or not and conduct estimations for pre and post inflation targeting periods. Interestingly enough, we find that inflation persistence was much higher for inflation targeters in periods before adopting their inflation targeting regimes and inflation persistence dropped by 40 percent for these countries after adopting the policy frameworks. For non-inflation targeters inflation persistence has increased by almost 290 percent between the two time periods.
\end{abstract}

Keywords: African countries; developing countries; inflation persistence; inflation targeting; panel data.

JEL Classification Codes: C1, E5

\section{Introduction}

Commitment to price stability forms the epitome of modern day monetary policy and Central Banks worldwide have undertaken this commitment, either by statutory mandates or by designated exercises of discretion (Phiri, 2016). It thus comes as no surprise that a considerable number of industrialized economies have entirely committed their monetary policy efforts towards adopting explicit inflation targeting regimes. However, such inflation targeting frameworks are less favoured in developing or emerging economies and this case becomes exceedingly obvious when taking into consideration African countries, in which only two countries (i.e. South Africa and Ghana) have explicitly adopted inflation targeting regimes as official monetary policy mandates. Naturally, this is a thought-provoking ordeal considering that inflation targeting is virtuous in curbing inflation expectations and lowering inflation volatility. Moreover, inflation targeting is built upon pillars like credibility, transparency, independence and accountability, which, in turn, are attributes of monetary policy necessary to

\footnotetext{
*E-mail: andrewp@cti.ac.za.

Citation: Phiri, A. (2016) Inflation persistence in African countries: Does inflation targeting matter?, Economics and Business Letters, 5(3), 65-71.
} 
ensure a stronger financial environment for African economies.

Regardless of whether Central Banks opt to adopt inflation targeting regimes or not, one thing remains certain; all monetary authorities wish to exert some level of control over prevailing levels of inflation. One particular attribute of the inflation process which serves as a guideline in determining whether Central Banks have appropriate control over inflation, relates to the amount of persistence found in the inflation process. As conveniently noted by Phiri (2012), an inflation process exhibiting low levels of persistence reflects a financial environment in which policymakers can control the inflation process. Conversely, high levels of inflation persistence signal the inability of Central Banks to control inflation such that any deviations of inflation from its steady-state will ensure that inflation does not easily adjust back its long-run equilibrium. The notion of inflation persistence can be theoretically traced to sticky price models and represents an inherent feature of staggered prices or wage contracts (Srinivasan and Kumar, 2012). Empirically, a popular measure of inflation persistence is the sum of regression coefficients (SARC) obtained after estimating an autoregressive (AR) model of inflation. If the SARC is equal to or above unity, then inflation is rendered to be highly persistent, and if the SARC is below unity, then inflation is not persistent.

In our study, we employ panel-data estimation techniques to evaluate inflation persistence for 46 African countries. We consider this research as being worthwhile since, to the best of our knowledge, no other study has conducted a panel data analysis of inflation persistence solely for African countries. Furthermore, we spilt our sample data into two categories, namely; inflation targeting and non-inflation targeting countries. The rationale behind examining inflation persistence between the two sets of data is quite simple. If inflation targeters are found to exhibit lower levels of inflation persistence in comparison to non-inflation targeters, then inflation targeting in African countries provides Central Banks with a greater degree of control over the inflation process. If the opposite holds true, then inflation targeting is not suited for African countries and other alternative monetary policy frameworks, such as exchange rate targets, are more compatible for African countries.

Against this backdrop, the rest of the paper is arranged as follows. The next section presents a brief review of economic theory supporting the meaningfulness of monetary policy guided by inflation targets whereas the data and methodology used in the study are presented in the third and fourth sections of the paper, respectively. The fifth section presents the empirical results whilst the paper is concluded in the sixth section.

\section{Theory of inflation targeting}

Inflation targeting is considered the state of art practice of modern day monetary policy conduct and this shown by the increasing number of Central Banks which have chosen inflation targeting as an official monetary policy mandate since New Zealand decided to first do so in 1990. The idea of inflation targeting came about as a result of the so-called monetary trilema which states that Central Banks can choose two out of three policy states at a given time. The three policy stances are flexible exchange rates, Central Bank independence (autonomy) and capital mobility. Choosing any two of this policy stance will result in forfeiting the privilege of the third policy stance. Most Central Banks are in consensus that Central Bank independence and capital mobility are the two most important policy stances hence inflation targeting is viewed as a suitable monetary policy given these options.

In practice, inflation targeting is a monetary policy strategy characterized by (i) an announced numerical inflation target (ii) an implementation of monetary policy that gives a major role to an inflation forecast (i.e. forecast targeting) (iii) high degree of transparency and accountability iv) institutional commitment in the form of a clear monetary policy mandate directed towards low inflation and central bank independence which ensures independence in 
setting the monetary policy instrument (Svensson, 1999). The theory which underlies inflation targeting is one of an optimal policy-rate path consisting of choices of targets and instruments which are not mutually exclusive (Veller and Ellyne, 2011). On one hand, the targeting rule is based on an explicit optimization problem based on setting policy in a way as to minimize an intertemporal loss function of the general form:

$$
E_{t} \sum_{\tau=0}^{\infty} \delta^{\tau}\left[\left(\pi_{t-\tau}-\pi^{*}\right)^{2}+\lambda \bar{y}_{t-\tau}^{2}\right]
$$

Where $E_{t}$ are expectations operator conditional on the set of information available at t, $\delta^{\tau}$ is a discount factor, $\pi_{t-\tau}$ a $\tau$-period-ahead inflation forecasts made at time $t, \pi^{*}$ is the Central Bank's target level of inflation and $\bar{y}$ is the output gap. On the other hand, the instrument rule is the monetary policy instrument expressed as an explicit function of the available information (Svensson, 2003). Classical examples of instrument rule include the McCallum (1988) rule for monetary base and the Taylor (1993) for the repo rate. However, since monetary targets were deemed unsuitable for monetary policy in the 1970's, Central Banks have typically relied on Taylor-type policy reactions functions for policy purposes. Typically these policy reactions functions depict that monetary authorities change the interest rate linearly in response to changes in the inflation and the output gap:

$$
i_{t}=i^{*}+\phi_{\pi}\left(\pi_{t}-\pi^{*}\right)+\phi_{y} \bar{y}_{t}
$$

Where $i_{t}$ is the nominal interest rate, $i *$ is its constant equilibrium level, $\pi^{*}$ is the target level of inflation, $\bar{y}_{t}$ is the output gap and $\phi_{\pi}$ and $\phi_{y}$ are subjective weights of the inflation gap and the output gap, respectively. The policy rules state that the repo rate it should be above it's longrun equilibrium level (i.e. $i_{t}<i^{*}$ ) when $i$ ) actual inflation is above its target (i.e. $\pi_{t}>\pi^{*}$ ) or/and ii) when the output gap is positive (i.e. $\bar{y}_{t}>0$ ). Conversely, the policy rule state that the repo rate should be kept below its equilibrium level (i.e. $i_{t}>i^{*}$ ) when $i$ ) actual inflation is below its target (i.e. $\pi_{t}>\pi^{*}$ ) and/or ii) output gap is negative (i.e. $\bar{y}_{t}<0$ ).

\section{Data}

The data used in the empirical part of the study consists of the annual rate of change in the total consumer price index (CPI) for a panel 46 African countries and has been collected from the Federal Reserve Economic Data (FRED) database for the period of 1994-2014. As previously mentioned, of all these countries only 2 countries (i.e. South Africa and Ghana) are inflation targeters while the remaining 44 countries represent non-inflation targeters. A comprehensive list of all 46 countries used in the study is provided in appendix A.

\section{Methodology}

In following Bleaney and Francisco (2005), we specify the following panel AR regression of inflation $\left(\pi_{t}\right)$ as:

$$
\pi_{t}=\rho \pi_{t-1}+e_{i}+u_{i}+v_{i t}
$$

Where $e_{i}$ is a country fixed effect, $u_{t}$ is a time fixed effect and $v_{i t}$ is the idiosyncratic error term. Countries are indexed by $i$ and time by $t$. From equation (1) inflation persistence is measured by the coefficient $\rho$, and the decision rule for assessing the level of persistence is as follows. If $\rho \geq 1$, then inflation is deemed as being persistent and otherwise if $\rho<1$. We estimate equation (1) for three panel sets of the data (the full sample, inflation targeters and non-inflation targeters) and we apply three estimation techniques to the regressions (OLS, fixed effects and random effects estimators). Evaluation of the regression estimators are conducted through (1) 
an F-test (F) to test for the null of fixed effects against the alternative of an OLS regression (2) Hausman's test $\left(\chi_{\text {hausen }}^{2}\right)$ of the null hypothesis of random effects against the alternative fixed effects, and (3) the Breusch-Pagan test $\left(\mathrm{LM}_{\mathrm{bp}}\right)$ of the null hypothesis of random effects against the alternative of OLS. The decision rules for these three evaluation tests are as follows. If we reject the null hypothesis of the first test and fail to reject the null of the second test, then we choose the fixed effects model. If we reject the null hypotheses of the second and the third tests, then we choose the random effects model. If we fail to reject the null hypotheses of the first and the third test, we choose the OLS specification.

\section{Empirical results}

Tables 1, 2 and 3 report our empirical estimation results for the full sample period, the preinflation targeting period and the post-inflation targeting period, respectively. In referring to Table 1, we note that for the full sample period of 1994 to 2014, inflation persistence is more than 5 times lower for non-inflation targeters (i.e. $\rho=0.14$ ) in comparison to inflation targeters (i.e. $\rho=0.72$ ). A similar result is also recorded in Table 2 for the pre-inflation period of 1994 to 2002, in which inflation persistence is approximately 5 times lower for non-inflation targeters ((i.e. $\rho=0.13$ ) than for inflation targeters (i.e. $\rho=0.75$ ). Table 3 paints a completely different picture as inflation persistence in inflation targeters (i.e. $\rho=0.45$ ) has been lower than that of its counterpart non-inflation targets (i.e. $\rho=0.51$ ) for the post inflation period of 2002 to 2014 . Based on these results, three main inferences can be drawn. Firstly, overall inflation in African countries has not been very persistent throughout the last two decades. Secondly, non-inflation targeters experienced lower levels of inflation persistence in pre-inflation targeting periods and yet this result was reversed in post-inflation targeting periods. Lastly, in transcending from the pre-inflation period to the post-inflation targeting period, inflation targeters reduced their inflation persistence by 40 percent whereas the levels of persistence in non-inflation targets has increased by more than 290 percent.

Table 1. Full sample period: 1994-2014.

\begin{tabular}{|c|c|c|c|c|c|c|c|}
\hline & \multicolumn{3}{|c|}{ Estimators } & \multirow[b]{2}{*}{ Decision } & \multicolumn{3}{|c|}{ Evaluation tests } \\
\hline & $O L S$ & $\begin{array}{l}\text { Fixed } \\
\text { effects }\end{array}$ & $\begin{array}{l}\text { Random } \\
\text { effects }\end{array}$ & & $\begin{array}{c}F \\
(\text { Fixed vs } \\
\text { OLS) }\end{array}$ & $\begin{array}{c}\chi_{\text {hausen }}^{2} \\
\text { (Random } \\
\text { vs fixed } \\
\text { effects) }\end{array}$ & $\begin{array}{c}L_{b p} \\
\text { (Random } \\
\text { effects vs } \\
\text { OLS) }\end{array}$ \\
\hline$\rho_{\text {full }}$ & $\begin{array}{c}0.14 \\
(0.00)^{* * *}\end{array}$ & $\begin{array}{c}0.07 \\
(0.05)^{*}\end{array}$ & $\begin{array}{c}0.13 \\
(0.00)^{* * *}\end{array}$ & $\begin{array}{l}\text { Random } \\
\text { effects }\end{array}$ & $\begin{array}{c}53.47 \\
(0.00)^{\#}\end{array}$ & $\begin{array}{c}1.17 \\
(0.22)\end{array}$ & $\begin{array}{c}0.03 \\
(0.87)\end{array}$ \\
\hline$\rho_{\text {IT }}$ & $\begin{array}{c}0.72 \\
(0.00)^{* * *}\end{array}$ & $\begin{array}{c}0.56 \\
(0.00)^{* * *}\end{array}$ & $\begin{array}{c}0.72 \\
(0.00)^{* * *}\end{array}$ & OLS & $\begin{array}{c}3.78 \\
(0.06)\end{array}$ & $\begin{array}{c}4.27 \\
(0.04)^{\#}\end{array}$ & $\begin{array}{c}0.02 \\
(0.88)\end{array}$ \\
\hline$\rho_{\text {NON-IT }}$ & $\begin{array}{c}0.14 \\
(0.00)^{* * *}\end{array}$ & $\begin{array}{c}0.01 \\
(0.05)^{*}\end{array}$ & $\begin{array}{c}0.13 \\
(0.00)^{* * *} *\end{array}$ & OLS & $\begin{array}{c}1.16 \\
(0.23)\end{array}$ & $\begin{array}{c}50.94 \\
(0.00)^{\#}\end{array}$ & $\begin{array}{c}0.02 \\
(0.88)\end{array}$ \\
\hline
\end{tabular}

Note: $\rho_{\text {full }}, \rho_{\text {IT }}$ and $\rho_{\text {NON-IT }}$ represent the SARC estimates for the whole sample, inflation targeters and non-inflation targeters, respectively. Significance codes: $1 \%$ '***, $5 \%$ ' $* *$ ' and $10 \%$ ' $*$ ' and p-values are reported in parentheses. \# on the evaluation tests indicates a rejection of the null hypothesis. 
Table 2. Pre-inflation targeting period: 1994-2002.

\begin{tabular}{|c|c|c|c|c|c|c|c|}
\hline & \multicolumn{3}{|c|}{ Estimators } & \multirow[b]{2}{*}{ Decision } & \multicolumn{3}{|c|}{ Evaluation tests } \\
\hline & $O L S$ & $\begin{array}{l}\text { Fixed } \\
\text { effects }\end{array}$ & $\begin{array}{l}\text { Random } \\
\text { effects }\end{array}$ & & $\begin{array}{c}F \\
(\text { Fixed vs } \\
\text { OLS) }\end{array}$ & $\begin{array}{l}\chi_{\text {hausen }}^{2} \\
\text { (Random } \\
\text { vs fixed } \\
\text { effects) }\end{array}$ & $\begin{array}{c}L M_{b p} \\
\text { (Random } \\
\text { effects } v \text { s } \\
\text { OLS) }\end{array}$ \\
\hline$\rho_{\text {full }}$ & $\begin{array}{c}0.13 \\
(0.01)^{*}\end{array}$ & $\begin{array}{l}-0.07 \\
(0.20)\end{array}$ & $\begin{array}{c}0.13 \\
(0.01)^{*}\end{array}$ & OLS & $\begin{array}{c}1.38 \\
(0.07)\end{array}$ & $\begin{array}{c}71.61 \\
(0.00)^{\#}\end{array}$ & $\begin{array}{c}0.01 \\
(0.93)\end{array}$ \\
\hline$\rho_{\mathrm{IT}}$ & $\begin{array}{c}0.75 \\
(0.00)^{* * *}\end{array}$ & $\begin{array}{c}0.40 \\
(0.14)\end{array}$ & $\begin{array}{c}0.75 \\
(0.00)^{* * *}\end{array}$ & OLS & $\begin{array}{c}3.61 \\
(0.00)^{\#}\end{array}$ & $\begin{array}{c}4.37 \\
(0.08)\end{array}$ & $\begin{array}{c}0.03 \\
(0.86)\end{array}$ \\
\hline$\rho_{\text {NON-IT }}$ & $\begin{array}{c}0.13 \\
(0.02)^{*} \\
\end{array}$ & $\begin{array}{l}-0.07 \\
(0.21) \\
\end{array}$ & $\begin{array}{c}0.13 \\
(0.01)^{*}\end{array}$ & OLS & $\begin{array}{c}1.38 \\
(0.07) \\
\end{array}$ & $\begin{array}{c}68.26 \\
(0.00)^{\#}\end{array}$ & $\begin{array}{c}0.01 \\
(0.93) \\
\end{array}$ \\
\hline
\end{tabular}

Note: $\rho_{\text {full }}, \rho_{\text {IT }}$ and $\rho_{\text {NON-IT }}$ represent the SARC estimates for the whole sample, inflation targeters and non-inflation targeters, respectively. Significance codes: $1 \%$ ' $* * *$ ', $5 \%$ ' $* *$ ' and $10 \%$ '*' and p-values are reported in parentheses. \# on the evaluation tests indicates a rejection of the null hypothesis.

Table 3. Post-inflation targeting period: 2002-2014.

\begin{tabular}{|c|c|c|c|c|c|c|c|}
\hline & \multicolumn{3}{|c|}{ Estimators } & \multirow[b]{2}{*}{ Decision } & \multicolumn{3}{|c|}{ Evaluation tests } \\
\hline & $O L S$ & $\begin{array}{l}\text { Fixed } \\
\text { effects }\end{array}$ & $\begin{array}{l}\text { Random } \\
\text { effects }\end{array}$ & & $\begin{array}{c}F \\
\text { (Fixed } \\
\text { vs OLS) }\end{array}$ & $\begin{array}{l}\chi_{\text {hausen }}^{2} \\
\text { (Random } \\
\text { vs fixed } \\
\text { effects) }\end{array}$ & $\begin{array}{c}L M_{b p} \\
\text { (Random } \\
\text { effects vs } \\
\text { OLS) }\end{array}$ \\
\hline$\rho_{\text {full }}$ & $\begin{array}{c}0.51 \\
(0.00)^{* * *}\end{array}$ & $\begin{array}{c}0.50 \\
(0.00)^{* * *}\end{array}$ & $\begin{array}{c}0.51 \\
(0.00)^{* * *}\end{array}$ & 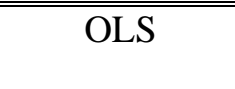 & $\begin{array}{c}0.80 \\
(0.81)\end{array}$ & $\begin{array}{c}1.54 \\
(0.21)\end{array}$ & $\begin{array}{c}0.17 \\
(0.68)\end{array}$ \\
\hline$\rho_{\mathrm{IT}}$ & $\begin{array}{c}0.45 \\
(0.00)^{* * *}\end{array}$ & $\begin{array}{c}0.11 \\
(0.47)\end{array}$ & $\begin{array}{c}0.45 \\
(0.00)^{* * *}\end{array}$ & $\begin{array}{l}\text { OLS/Random } \\
\text { effects }\end{array}$ & $\begin{array}{l}11.30 \\
(0.00)^{\#}\end{array}$ & $\begin{array}{c}7.32 \\
(0.01)^{\#}\end{array}$ & $\begin{array}{l}1.90 \\
(0.18)\end{array}$ \\
\hline$\rho_{\text {NON-IT }}$ & $\begin{array}{c}0.51 \\
(0.01)^{* * *}\end{array}$ & $\begin{array}{c}0.50 \\
(0.00)^{* * *}\end{array}$ & $\begin{array}{c}0.51 \\
(0.00)^{* * *}\end{array}$ & OLS & $\begin{array}{c}0.78 \\
(0.84)\end{array}$ & $\begin{array}{c}1.28 \\
(0.23)\end{array}$ & $\begin{array}{c}0.26 \\
(0.61)\end{array}$ \\
\hline
\end{tabular}

Note: $\rho_{\text {full }}, \rho_{\text {IT }}$ and $\rho_{\text {NON-IT }}$ represent the SARC estimates for the whole sample, inflation targeters and non-inflation targeters, respectively. Significance codes: $1 \%$ ' $* * *$ ', $5 \%$ ' $* *$ ' and $10 \%$ ' $*$ ' and p-values are reported in parentheses. \# on the evaluation tests indicates a rejection of the null hypothesis.

\section{Conclusion}

Do inflation targeters exhibit lower levels of inflation persistence in African countries in comparison to their non-inflation targeting counterparts? Our estimation results prove that the introduction of inflation targeting policy frameworks has resulted in lower levels of inflation persistence in inflation targeters compared to other non-inflation targeting economies. In particular, inflation persistence in inflation targeters have been reduced by 40 percent from preinflation targeting to post-inflation targeting periods whereas for non-inflation targeters, levels of inflation persistence have increased by close to 290 percent across the two sample periods. Collectively, these results show that inflation targeting policy framework has the capability of improving the control which Central Banks in African countries exert over their inflation levels.

\section{References}

Bleaney, M. and Francisco, M. (2005) Inflation persistence and exchange rate regimes: Evidence from developing countries, Economics Bulletin, 6(2), 1-15.

McCallum, B. (1988) Robustness properties of a rule for monetary policy, Carnegie-Rochester Conference Series on Public Policy, 29, 173-204. 
Phiri, A. (2012) Threshold effects and inflation persistence in South Africa, Journal of Financial Economic Policy, 4(3), 247-269.

Phiri, A. (2016) Inflation persistence and monetary policy in South Africa: Is the $3 \%$ to $6 \%$ percent inflation target too persistent, International Journal of Sustainable Economy, $8(2), 111-124$.

Srinivasan, N. and Kumar, P. (2012) Inflation persistence: Does credibility of the monetary regime matter, Economics Bulletin, 32(4), 2944-2954.

Svensson, L. (1999) Inflation targeting as a monetary policy rule, Journal of Monetary Economics, 43(3), 607-654.

Svensson, L. (2002) Inflation targeting: Should it be modeled as an instrument or a target rule?, European Economic Review, 46(4-5), 771-780.

Taylor, J. (1993) Discretion versus policy rules in practice, Carnegie-Rochester Conference Series on Public Policy, 39, 195-214.

Veller, C. and Ellyne, M. (2011) What is the SARB's inflation targeting policy, and is it appropriate?, MPRA Working Paper 42134, Munich, Bavaria. 


\section{Appendix A}

\section{List of 46 African countries included in the study}

Table 4. List of 46 African countries included in the study.

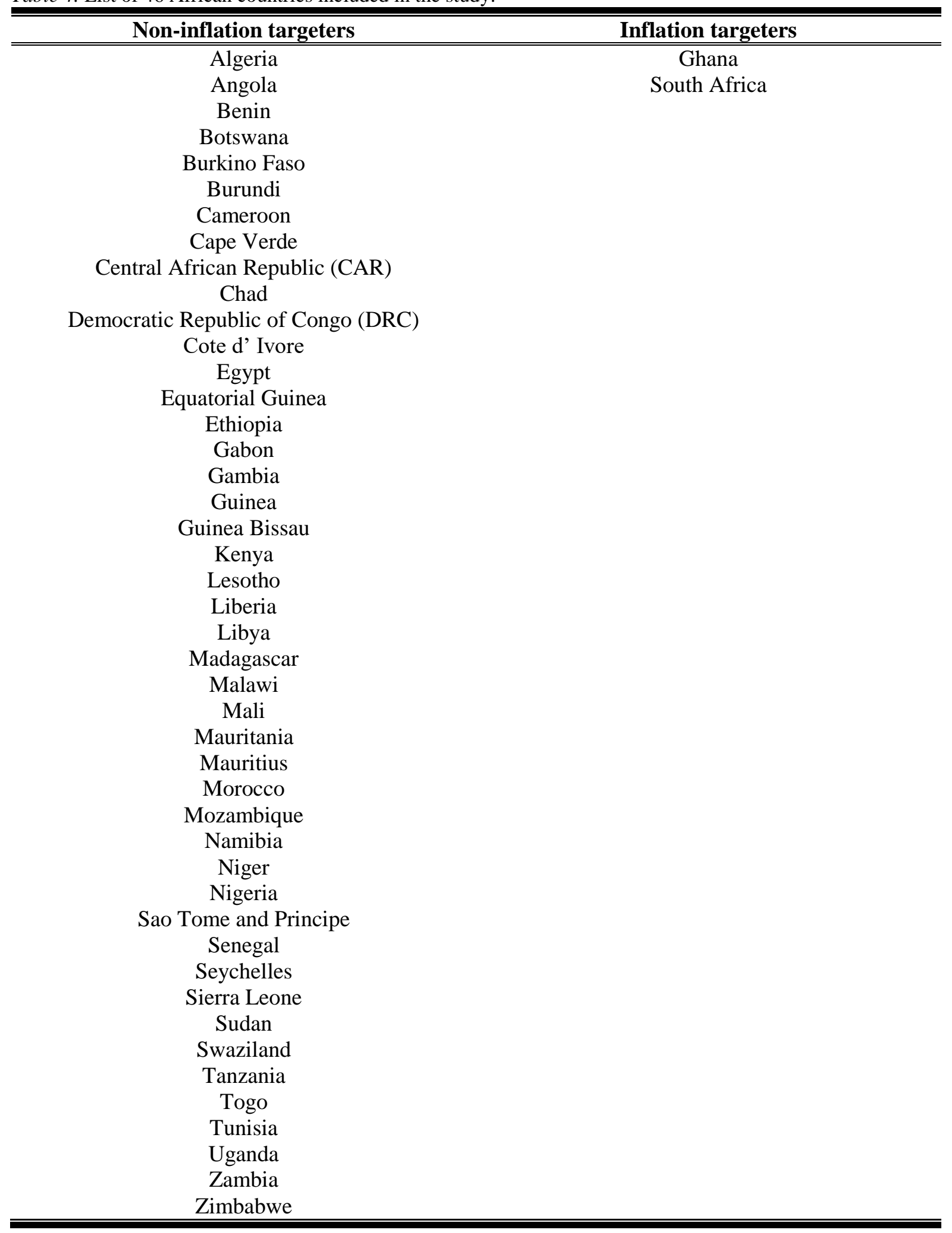

